13. Радивиловський Антоній. Вінець Христов. Київ: Типографія Києво-Печерської Лаври, 1688. Арк.133.

14. Римський градуал з Григоріанським календарем. Антверпен, 1599.

15. Римський градуал. Краків: Типографія Великої колегії Краківського університету, 1740.

16. Psalterium. [Краків], XVI ст. Арк. 46 (Ps. LII : Dixit incipiens in corde non est Deus).

DOI https://doi.org/10.30525/978-9934-26-004-9-28

\title{
СИНТЕЗ УКРАЇНСЬКОЇ ТА ІТАЛІЙСЬКИХ ТРАДИЦІЙ В АРХІТЕКТУРІ КИСВА ХVIII - ХІХ СТОЛІТТЯ (НА ПРИКЛАДІ ТВОРЧОСТІ Ф. РАСТРЕЛЛІ ТА РОДИНИ БЕРЕТТІ)
}

\author{
Кузьмінець Н. П. \\ кандидат історичних наук, доцент, \\ доцент кафедри історії та культури Украӥни \\ Стадник О. О. \\ кандидат історичних наук, \\ доцент кафедри історії та культури Украӥни \\ Вінницького державного педагогічного університету \\ імені Михайла Коиюбинського \\ м. Вінниця, Украӥна
}

У кінці ХУІІІ-ХІХ столітті українська архітектура розвивалася у руслі європейських традицій, згідно з їх тенденціями та стильовими напрямами. Вона постійно збагачувалася та удосконалювалася, поповнювалася новими композиційними елементами. Українські майстри запозичували головні принципи будівництва європейських споруд, використовували планування палацово-паркових ансамблів, запрошували до співпраці провідних зарубіжних митців. Особливе місце серед них належить відомим архітекторам італійського походження Франческо Бартоломео Растреллі та родині Беретті - батькові Вінченцо і сину Алессандро, за проєктами та під безпосереднім керівництвом яких було зведено багато споруд у Києві. Ці непересічні будівлі по праву відносять до світової культурної скарбниці. Можна стверджувати, що вони докорінно змінили архітектурне обличчя міста, перетворивши його на справжню європейську столицю. I до 
сьогоднішнього часу ці пам'ятки займають одне із чільних місць серед архітектурних візитівок сучасного Києва.

Метою статті $\epsilon$ показ внеску відомих діячів європейської архітектури у формування національного архітектурного мистецтва.

Життя і діяльність видатних зодчих розкрита в багатьох наукових та публіцистичних публікаціях як узагальнюючого, так і спеціалізованого напрямку. Дана проблема була предметом наукового зацікавлення дослідників Дегтярьова М. [1], Зубкова С. [2], Кальницького М. [3], Мироненка Д. [4], Салати С. [5], Степовика Д. [6], Фоменка С. [7]. За проєктом Бартоломео Растреллі побудовано дві пам'ятки в архітектурному ансамблі Києва - Андріївська церква та Маріїнський палац.

У 1715 році Бартоломео Растреллі приймає пропозицію Петра I переїхати 3 Парижа до Петербурга для розбудови нової російської столиці. Збудувавши Анічков палац, Смольний монастир з розкішним собором, великий Петербурзький палац, Скатеринінський та Зимовий палаци, він створює неповторний вигляд Петербурга. За правління Слизавети Петрівни Растреллі разом з імператрицею відвідує Київ та за іiі бажанням починає працювати над проєктом церкви св. Андрія. Перший камінь в іiі будівництво було закладено в 1744 році. Однак початок будівельних робіт затягнувся до 1749 року. Андріївську церкву планувалося збудувати у центральній частині Києва, на найвищій місцині над Подолом, на Старокиївській горі. Растреллі швидко розробив креслення, однак організатором будівельних робіт та їх керівником став інженер Іван Мічурін. Вчені сперечаються чи відвідував Растреллі Київ та особисто керував будівельними роботами. Оригінальні креслення майстра до цих пір зберігаються у віденській галереї «Альбертина». Наразі побутує думка, що Растреллі зовсім не займався проєктуванням храму, а використав для нього один із ранніх варіантів проєкту Смольного монастиря, який не був затверджений імператрицею як дуже невеликий за розміром [8, арк. 7286]. Однак порівняльний аналіз креслень Смольного i креслень 3 «Альбертини» плану i фасаду Андріївської церкви спростовують іiі. Сучасна архітекторка та дослідниця В. Корнєєва стверджує, що майстер до України не приїздив. На підтвердження цієї думки наводить такі аргументи: по-перше, проєкт укріплення печер був лише підписаний Растреллі, а виконаний інженерпідполковником київської залоги Де-Боскета [9, с. 43], по-друге, 3 листування Растреллі з Мічуріним стає зрозумілим, він не врахував крутизну підйому при будівництві пандусу для в”їзду карет [10, с. 23]. Оскільки зодчий на будівництві присутнім не був, не знав рельєфу і природних особливостей місцевості, його проєкт не міг бути втілений у життя. Будівлі загрожували зсуви грунтів, насичених підземними джерелами. Тому потрібно було робити міцний фундамент i не 110 
переобтяжувати вагу прикрас. За початковим проєктом Растреллі вони мали бути відлиті з чавуну та оздоблені золоченими гірляндами. Однак Мічурін запропонував використати обпалену глину - теракот. За його ж пропозицією було заглиблено фундамент та зроблено цокольний поверх 3 цокольними перемичками. Наступні видозміни були зроблені вже за недостатністю коштів. Так, куполи були вилиті з заліза, не позолочені, а пофарбовані звичайною олійною фарбою. Споруда характеризується багатством і насиченістю декору. Доказом цього збережений виконавчий кресленник фасаду церкви, складений київським міським архітекторм А. Меленським у 1800 році для іï ремонту [11, арк. 67]. Фасад був прикрашений колонами, пілястрами, ліпниною. Інтер'єр церкви має світський палацовий характер. Найвідомішим іiі декоративним компонентом $є$ іконостас, виготовлений у техніці різьблення петербурзькими майстрами за кресленнями Растреллі, який зберігся в незмінному вигляді [12, с. 451]. Церква $є$ діючою до сьогодні, зараз виконує роль резиденції Вселенського патріарха Варфоломія і представництва Вселенської Константинопольської церкви.

Маріїнський палац було закладено у тому ж 1744 році. Його планували зробити Київською резиденцією імператриці. Палац - це композиція з трьох корпусів, двоповерхового центрального і двох бічних одноповерхових флігелів. За початковим задумом перший поверх палацу мав бути кам'яним, мав використовуватися для побутових потреб. На другому, дерев'яному, мало розташовувуватися 28 парадних кімнат 3 парадним декором. Будівництво споруди було закінчено у кінці XVIII століття при Катерині II, подальша реконструкція проводилася при Олександрі II, на честь його дружини Марії Олександрівни у $30-x$ роках XIX століття його назвали Маріїнським. Тоді ж на території палацу було розбито великий парк з фонтанами та скульптурними композиціями [13, с. 567]. За період існування палац підлягав неодноразовим реконструкціям. Останні реставраційні роботи тривали з 2007 по 2020 рік. В незалежній Україні він є офіційною резиденцією Президента, місцем, де відбуваються усі державні урочистості.

Ще однією сторінкою історії архітектури Києва була творчість батька і сина Беретті, які в кінці 30-х років XIX століття жили і працювали в українській столиці. За проєктами Вінченцо (Вікентія) було збудовано Червоний корпус Київського університету, Університет шляхетних дівчат, Астрономічну обсерваторію та Ботанічний сад; Алессандро (Олександра) - Першу київську гімназію, Анатомічний театр та Володимирський собор. Жодної із споруд у закінченому вигляді батько так і не дочекався. Закінчував їх будівництво його син.

У 1837 році київська міська влада залучила Вінченцо Беретті до розробки генерального плану забудови міста. Важливою його частиною 
мав стати ансамбль споруд Київського університету Святого Володимира. Його розташування мало бути узгоджено 3 прилеглими будинками та вулицями, про що свідчить листування архітектора 3 генерал-губернатором міста [14, с. 11]. Однак, через дороговизну проєкту було затверджено забудову лише двох кварталів поблизу університету. Будинок університету задумано як споруду палацового типу із замкнутим двором, своїм величним зовнішнім виглядом він мав створити враження монолітної будови з цілого каменю на гранітній основі. Для прикраси фасаду автор використав ордерні колони та пілястри різної форми, фігурні карнизи, модульйони, порізи [15, арк. 1, 1зв.]. Внутрішній простір будівлі передбачав коридорну систему, однак, завдяки вдалим розміщенням аудиторій та симетричним компонуванням приміщень автор домігся усунення одноманітності і казарменної сухості стилю. Приміщення університету планувалося пофарбувати у кілька кольорів. Аудиторії і коридори мали бути однотонними, бібліотека і парадні зали прикрашені розписом, фресками, барельєфами і ліпниною. Але після смерті майстра його син відмовився від декорування, і живописні роботи, задумані Вінченцо, не відбулися. Проєкт Астрономічної обсерваторії також не був реалізований до кінця. Його кілька разів переробляли та спрощували. До складу обсерваторії увійшли головна будівля, лабораторно-житловий комплекс, професорський флігель, обсерваторна гілка, меридіанний круг, рефрактор, сонячний телескоп та прилегла паркова зона. Усі вони нині $є$ пам'ятками історії, науки і техніки, архітектури і містобудування [16, с. 261]. За головним корпусом університету Беретті планував розбити Ботанічний сад та парк у англійському стилі [17, с. 233]. Систему університетських споруд доповнив Анатомічний театр, збудований за проєктом О. Беретті в 1850-х роках, який став одним із найвідоміших у Свропі [18, с. 118]. За часів незалежної України з 1999 року він є Національним музеєм медицини України.

Ще однією перлиною київського зодчества став Володимирський собор, спроєктований О. Беретті у 1862 році. Будівництво собору велося 3 перервами протягом 20 років. I лише в 1896 році відбулося його урочисте освячення. 31992 року був Патріаршим кафедральним собором православної конфесії.

Отже, творчість Растреллі і Беретті - ціла епоха в історії столиці. Вони залишили місту і Україні унікальні пам'ятки архітектури, які $\epsilon$ їх окрасою і у наш час. Вони потребують державної підтримки, дбайливого ставлення, популяризації серед широкого загалу населення та подальших досліджень науковців. 


\section{Література:}

1. Дегтярьов М.Г., Корєєва В. Андріївська церква: монографія. Київ: Техніка, 1999. $120 \mathrm{c}$.

2. Зубков С. Андріївська церква. СтройПрайс. 2007. № 29. С. 8-9.

3. Кальницкий М. Зодчество и зодчие. Киев: Варта, 2012. 279 с.

4. Мироненко Д. Церква-символ. Будівниитво Украӥни. 2014. № 3. C. $42-45$.

5. Салата С.А. До питання історії створення комплексу «Астрономічна обсерваторія Київського університету св. Володимира. Пращуі центру пам'яткознавства. Випуск 24. 2013. С. 256-266.

6. Степовик Д. Володимирський собор: Історія, архітектура, малярство собору в Києві. Наукове мистецтвознавче видання. К.: Дніпро, $2015.375 \mathrm{c}$.

7. Фоменко С. Франческо Бартоломео Растрелли. Москва: ДиректМедиа, 2014. 72 с.

8. РДІА. Ф.470. Оп.75. Спр. 7335.

9. Корнєєва В. Андріївська церква у Києві. Пам'ятки Украӥни. 1997. № 1. C. 43-45.

10. Мердер А. Киевский храм св. Апостола Андрея Первозванного. К.: Тип. Имп.Ун-та Св. Владимира, 1898. 18 с.

11. ДАКО. Ф. 1. Оп. 319. Спр. 334.

12. Янченко Л.В. Розташування ікони в іконостасі Андріївської церкви Науковий вісник музею історії Украӥни. Випуск 4. 2019. C. 445-456.

13. Українська дипломатична енциклопедія: У 2-х т. / гол. Ред. Л. В. Губерський. К.: Знання України, 2004. Т. 2. 812 с.

14. Бутник-Сіверський В.С. Архітектор В.І. Бекетті в Києві. Київ: Держтехвидав України, 1947. 44 с.

15. ЦДІАК України. Ф. 442. Оп 1. Спр. 5124.

16. Салата С.А. До питання історії створення комплексу «Астрономічна обсерваторія Київського університету Св. Володимира. Прачі Центру пам'яткознавства. Вип.24. Київ. 2013 . С. 256-266.

17. Шпагін В.Ф. Концепція створення історичного парку у парковій частині Ботанічного саду Київського національного університету імені Т. Шевченка. Сучасні проблеми архітектури та містобудування. Вип. 42. 2016. С. 231-240.

18. Шипулін В.П., Догузов В.Д. Анатомічний театр університету Святого Володимира (До 160-річчя 3 дня відкриття). Гастроентерологія. № 2(48). 2013. С. 116-120. 